\title{
Fitoremediasi Logam Fe dalam Air Asam Tambang Menggunakan Eceng Gondok (Eichhornia Crassipes)
}

\author{
Fitoremediation of Heavy Metal Fe in Mining Acid Water with Water Hyacinth (Eichhornia \\ crassipes)
}

\author{
Fachruddin Azwari ${ }^{* 1}$, Joko Triyono ${ }^{2}$ \\ ${ }^{1,2}$ Program Studi Pengelolaan Lingkungan, Politeknik Pertanian Negeri Samarinda, Indonesia \\ ${ }^{*}$ Correspondence Author: fahriazwari@yahoo.com
}

\begin{abstract}
ABSTRAK
Kegiatan pertambangan mengakibatkan dampak negatif terhadap lingkungan berupa pencemaran. Salah satu unsur penyebab yaitu air asam tambang (AAT) yang mengandung besi sulfur, seperti pirit $\left(\mathrm{FeS}_{2}\right)$ dan pirotit (FeS) yang dapat mencemari air permukaan dan air tanah, mengganggu kesehatan masyarakat sekitar Fitoremediasi berupa penggunaan tanaman untuk menghilangkan, memindahkan, menstabilkan atau menghancurkan bahan pencemar baik itu senyawa organik maupun anorganik. Penelitian ini bertujuan untuk menganalisa kandungan logam Fe dalam air asam tambang secara fitoremediasi dengan media eceng gondok. Penelitian dilakukan dengan mengambil sampel air di setlling pond yang tidak aktif pada aliran kompartemen kedua di perusahaan batubara CV. Arjuna dan analisa sampel dilakukan di Laboratorium Budidaya Perairan Fakultas Perikanan dan IImu Kelautan Universitas Mulawarman Samarinda. Hasil fitoremediasi menggunakan eceng gondok yang dianalisa menggunakan AAS kandungan logam Fe sebelum fitoremediasi $0,382 \mathrm{mg} / \mathrm{l}$ dan sesudah fitoremediasi mengalami penurunan menjadi $0,379 \mathrm{mg} / \mathrm{l}$ sampai tidak terdeteksi.
\end{abstract}

Kata Kunci : Air Asam Tambang, Eceng Gondok, Fitoremediasi, Logam Fe.

\begin{abstract}
Mining activities have a negative impact on the environment in the form of pollution. One of the causes is mining acid Water (AAT) containing iron sulfur, such as pyrite (FeS2) and pyrotite (FeS) which can contaminate surface water and ground water, disturbing the health of the surrounding community. Pollutants to both organic and inorganic compounds. This study aims to analyze the Fe metal content in acid mine drainage by phytoremediation with water hyacinth media. The study was conducted by taking water samples in an inactive pond setting in the second compartment flow in the coal company CV. Arjuna and sample analysis were conducted at the Aquaculture Laboratory of the Faculty of Fisheries and Marine Sciences, Mulawarman University, Samarinda. The results of phytoremediation using water hyacinth were analyzed using AAS Fe metal content before phytoremediation $0.382 \mathrm{mg} / \mathrm{I}$ and after phytoremediation decreased to $0.379 \mathrm{mg} / \mathrm{I}$ until undetected.
\end{abstract}

Keywords: Acid Mine Water, Fe Metal, Phytoremediation, Water Hyacinth

\section{PENDAHULUAN}

Kegiatan pertambangan untuk mengambil bahan galian berharga dari lapisan bumi telah berlangsung sejak lama dan akan mengakibatkan dampak buruk terhadap lingkungan. Salah satu dampak buruk yaitu pencemaran dengan unsur penyebab yaitu air asam tambang (AAT) yang mengandung besi sulfur, seperti pyrite $\left(\mathrm{FeS}_{2}\right)$ dan pyrotit (FeS) yang dapat mencemari air permukaan dan air tanah, mengganggu kehidupan flora fauna dan kesehatan masyarakat sekitar (Fahruddin, 2010). Pembentukan air asam tambang
(AAT) atau dalam bahasa Inggris dikenal dengan "Acid Mine Drainage (AMD)" atau " Acid Rock Drainage (ARD)" terbentuk dari oksidasi mineral yang mengandung besi sulfur, seperti pirit $\left(\mathrm{FeS}_{2}\right)$ dan pirotit $(\mathrm{FeS})$ oleh oksidator seperti air dan oksigen. Hasil oksidasi pyrite membentuk air asam tambang dengan $\mathrm{pH}$ 2-4 yang bisa menyebabkan menurunnya kualitas air permukaan. Logam yang terkena air dengan kondisi $\mathrm{pH}$ seperti ini bisa terlarut dan meningkatkan dampak pencemaran terhadap lingkungan.

Logam $\mathrm{Fe}$ merupakan unsur penting dalam air permukaan dan air tanah. Perairan yang mengandung $\mathrm{Fe}$ apabila digunakan 
untuk keperluan rumah tangga menyebabkan bekas karat pada pakaian, porselin dan alatalat lainnya serta menimbulkan rasa tidak enak pada air minum jika konsentrasinya \pm 0,31 mg/l (Achmad, 2004).

Apabila air sungai telah terkontaminasi oleh air asam tambang maka akan berdampak pada penurunan populasi biota di perairan dan kemampuan biota dalam bertahan hidup. Logam berat seperti besi, tembaga, seng yang terkandung dalam tanah yang asamnya tinggi pada dasarnya merupakan unsur hara mikro yang dibutuhkan tanaman, sementara unsur hara makro yang dibutuhkan tanaman seperti fosfor, magnesium, kalsium sangat kurang, akibatnya keracunan pada tanaman karena kelebihan unsur hara mikro, ini ditandai dengan membusuknya akar tanaman sehingga tanaman menjadi layu (Herniwanti et al. 2014). Dampak air asam tambang tidak dirasakan secara langsung oleh masyarakat tetapi apabila dalam waktu panjang kandungan logam $\mathrm{Fe}$ akan terakumulasi di dalam tubuh makhluk hidup (ikan dan tumbuhan) dan apabila dikonsumsi oleh masyarakat akan menyebabkan gangguan kesehatan seperti penyakit minamata, bibir sumbing, kerusakan susunan syaraf dan cacat pada bayi. Air asam tambang yang mengadung logam berat, yang mengalir ke sungai, danau atau rawa akan merusak kondisi ekosistem yang ada disungai tersebut. Hal ini tentu saja akan menyebabkan adanya penurunan kualitas air. Selain itu air asam tambang dapat mempengaruhi bentang alam, perubahan struktur tanah, perubahan pola aliran permukaan dan air tanah serta komposisi kimia air permukaan.

Fitoremediasi adalah suatu teknologi yang menggunaan tanaman untuk memperbaiki sebagian atau subtansi kontaminan tertentu dalam tanah, endapan, kotoran/lumpur, air tanah, air permukaan, dan air sampah. Melalui metode ini air tambang dapat dikelola untuk meminimalisir penyebab terjadinya dampak lingkungan yang utama (Ariyani et al. 2014).

Risalah eceng gondok adalah sebagai berikut (Anonim, 2012):

Kerajaan : Plantae

Divisi : Magnoliophyta

Kelas : : Liliopsida

Ordo : Commelinales
Famili : Pontederiaceae

Genus : Eichhornia

Spesies : E. crassipes Martius

Eceng gondok memiliki kecepatan tumbuh yang tinggi sehingga tumbuhan ini dianggap sebagai gulma yang dapat merusak lingkungan perairan. Eceng gondok hidup mengapung di air dan kadang-kadang berakar dalam tanah. Kemampuan untuk beradaptasi dan pertumbuhannya yang cepat mejadikan Eceng gondok sebagai fitoremediator yang bagus. Eceng gondok dan kayu apu telah terbukti dapat menurunkan pencemaran yang diakibatkan limbah air asam tambang (Ariyani et al. 2014)

Penelitian ini bertujuan untuk menganalisa kandungan logam $\mathrm{Fe}$ dalam air asam tambang dengan perlakuan fitoremediasi menggunakan eceng gondok. Hasil yang diharapkan dalam penelitian ini adalah tanaman eceng gondok mampu menurunkan logam $\mathrm{Fe}$ dalam air asam tambang.

\section{METODE PENELITIAN}

\section{Lokasi dan Waktu Peneltian}

Penelitian dilakukan dengan mengambil sampel air di setlling pond yang tidak aktif pada aliran kompartemen kedua di perusahaan batubara CV. Arjuna dan analisa sampel dilakukan di Laboratorium Tanah dan Air Politeknik Pertanian Negeri Samarinda.

Penelitian dilaksanakan selama dua bulan terhitung sejak penyiapan bahan sampai pengolahan data dimulai dari bulan Mei sampai Juli 2018

\section{Bahan dan Alat Penelitian}

Bahan dan alat penelitian yang digunakan adalah sebagai berikut:

- Eceng Gondok sebanyak 2 rumpun.

- Sampel air asam tambang sebanyak 20 liter.

- Larutan standar $\mathrm{Fe}(4,8,10,12,16,20$ ppm).

- Atomic Absorption Spectroscopy (AAS) untuk mengukur kadar $\mathrm{Fe}$.

- Jerigen untuk tempat menampung sampel air pada saat pengambilan di lapangan.

- Bak berukuran $50 \times 100 \mathrm{~cm}$, untuk menampung sampel dan media eceng gondok. 
- Kalkulator, untuk memudahkan penghitungan nilai parameter uji.

- $\quad$ ATK, untuk membantu dalam penulisan proses penelitian.

\section{Prosedur penelitian}

Menganalisa sampel air sebelum fitoremediasi sebagai kontrol untuk mengetahui nilai kandungan $\mathrm{Fe}$ dengan menggunakan Atomic Absorption Spectroscopy (AAS).

Memasukkan sampel air sebanyak 20 liter dan eceng gondok sebanyak 2 rumpun ke dalam bak.
Menganalisa sampel air selama fitoremediasi berlangsung setiap dua hari sekali selama satu minggu untuk mengetahui perubahan nilai kandungan Fe.

Pengolahan data

Analisa data yang digunakan dalam penelitian ini adalah analisa data secara tabulasi dan grafik.

\section{Hasil}

\section{HASIL DAN PEMBAHASAN}

Berdasarkan hasil analisa diperoleh kandungan logam Fe sebelum dan sesudah fitoremediasi dapat dilihat pada tabel dan gambar berikut:

Tabel 1. Hasil Analisa Kadar Fe Sebelum dan Sesudah Fitoremidiasi

\begin{tabular}{ccc}
\hline Hari Ke- & Perlakuan & Hasil \\
\hline 0 & Sebelum menggunakan eceng gondok & $0,382 \mathrm{mg} / \mathrm{l}$ \\
2 & Menggunakan eceng gondok & $0,379 \mathrm{mg} / \mathrm{l}$ \\
4 & Menggunakan eceng gondok & TTD \\
6 & Menggunakan eceng gondok & TTD \\
\hline
\end{tabular}

Keterangan:

Tabel 2. Hasil Analisa pH Sebelum dan Sesudah Fitoremidiasi

\begin{tabular}{ccc}
\hline Hari Ke- & Perlakuan & Hasil \\
\hline 0 & Sebelum menggunakan eceng gondok & 3 \\
2 & Menggunakan eceng gondok & 5,7 \\
4 & Menggunakan eceng gondok & 6,5 \\
6 & Menggunakan eceng gondok & 7,2 \\
\hline
\end{tabular}

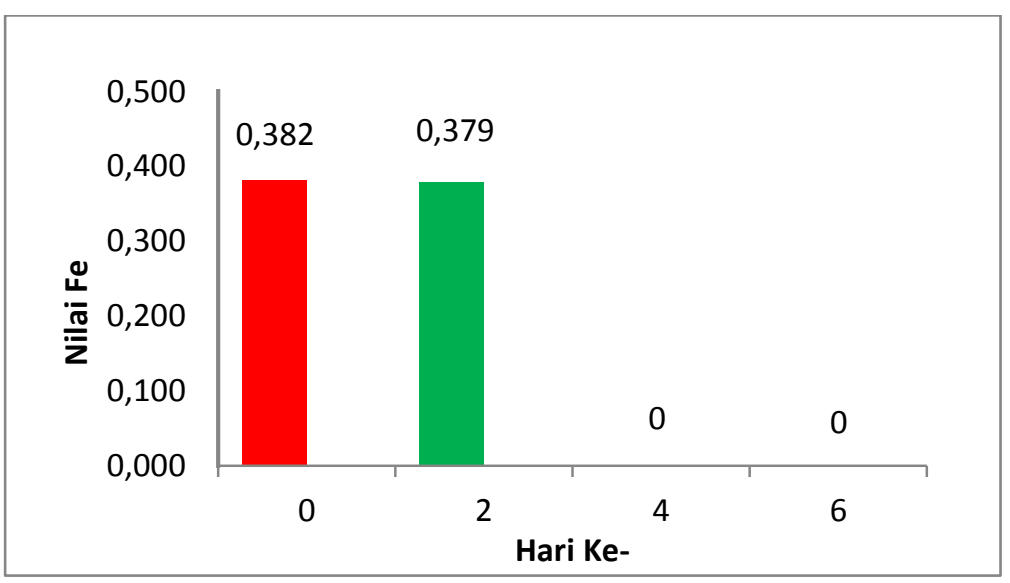

Gambar 1.Grafik Penurunan Kadar Logam Fe dalam Air Asam Tambang 


\section{Pembahasan}

Dari hasil uji analisa di Laboratorium telah diketahui kandungan logam Fe sebelum fitoremediasi menggunakan eceng gondok yaitu 0,382 $\mathrm{mg} / \mathrm{l}$, kandungan tersebut adalah kandungan logam $\mathrm{Fe}$ awal sampel air asam tambang sebagai kontrol untuk mengetahui perubahan logam $\mathrm{Fe}$ saat remediasi. Kandungan logam $\mathrm{Fe}$ dalam air asam tambang pada umumnya tinggi. Saat remediasi berlangsung yaitu pada hari kedua proses penyerapan logam $\mathrm{Fe}$ yang terdapat dalam air asam tambang, ini dilakukan oleh ujung-ujung akar dengan jaringan meristem karena adanya gaya tarik menarik oleh molekul-molekul air yang ada pada tumbuhan. Logam Fe yang telah diserap oleh akar akan masuk kebatang melalui pembuluh pengangkut (xilem), yang kemudian akan diteruskan ke jaringan tumbuhan (Subroto, 1996). Dari proses penyerapan oleh akar kandungan logam $\mathrm{Fe}$ mengalami penurunan menjadi 0,379 $\mathrm{mg} / \mathrm{l}$.

Dari analisa pada hari ketiga dan keempat kandungan logam $\mathrm{Fe}$ mengalami penurunan sampai tidak terdeteksi oleh AAS, ini disebabkan karena akar eceng gondok telah menyerap lebih banyak logam Fe dari hari sebelumnya. Logam $\mathrm{Fe}$ sebelum dan sesudah fitoremediasi masih di bawah ambang baku mutu air limbah pertambangan batubara (Perda Kaltim No. 2 Tahun 2011 dengan parameter Fe yaitu $7 \mathrm{mg} / \mathrm{l}$ ).

Analisa $\mathrm{pH}$ sebelum remediasi yaitu 3 sebagai kontrol untuk mengetahui perubahan $\mathrm{pH}$ saat remediasi, analisa pada hari kedua $\mathrm{pH}$ menjadi 5,7 dan hari ketiga dan keempat menjadi 6,5 dan 7,2 .

Setelah remediasi dan analisa logam $\mathrm{Fe}$ selesai pada hari keempat eceng gondok mengalami perubahan yaitu timbulnya bercak kuning pada daun dan sebagian telah layu, selang beberapa waktu eceng gondok mati. Perubahan pada eceng gondok karena translokasi dan terakumulasi logam Fe ke bagian jaringan tumbuhan seperti akar, daun, batang.

Kemampuan Eceng gondok untuk melakukan Fitoremediasi dengan cara Rizofiltrasi yaitu dengan pemanfaatan kemampuan akar untuk menyerap, mengendapkan dan mengakumulasi logam dari aliran limbah, ini umumnya untuk membersihkan lingkungan akuatik. Namun logam berat $\mathrm{Fe}$ tersebut akan terakumulasi dalam batang dan daun Eceng gondok sehingga mengakibatkan tanaman menjadi berwarna kuning dan layu. Logam Fe yang diserap oleh Eceng gondok melebihi dari kemampuan tanaman Eceng gondok untuk dimanfaatkan dalam proses metabolisme sehingga logam Fe justru menjadi racun bagi Eceng gondok karena melebihi kemampuan daya dukungnya.

\section{KESIMPULAN DAN SARAN}

Hasil fitoremediasi menggunakan eceng gondok yang dianalisa menggunakan AAS kandungan logam $\mathrm{Fe}$ sebelum fitoremediasi 0,382 $\mathrm{mg} / \mathrm{l}$ dan sesudah fitoremediasi mengalami penurunan menjadi $0,379 \mathrm{mg} / \mathrm{l}$ sampai tidak terdeteksi.

Penelitian selanjutnya diharapkan adanya pengembangan metode dan parameter yang diamati untuk mengetahui kandungan logam dalam air asam tambang.

\section{DAFTAR PUSTAKA}

Achmad, R. 2004. Kimia Lingkungan. Andi. Yogyakarta.

Ariyani, D., Ramlah, S., Umi, B.L.U., Rd Indah, N. (2014). Kajian Adsopsi Logam Fe dan Mn oleh Tanaman Purun Tikus (Eleocharis dulcis) pada Air Asam Tambang secara Fitoremediasi. Sains dan Terapan Kimia. 8 (2). 87-93.diakses tanggal 21 Desember 2019

Fahruddin, 2010. Bioteknologi Lingkungan. Alfabeta. Bandung.

Herniwanti, J B Priatmadi, B Yanuwiadi, and Soemarno. 2014. Penanganan Air Asam Tambang Dengan Cara Fitoremediasi Tanaman (Pasif). Journal of Applied Environmental and Biological Sciences 4(3): 167- 76 .

Subroto, M. A. 1996. Fitoremediasi Dalam Pengelolaan Lingkungan. Cibinong. 